\title{
Internet-Based Materials in Enhancing College Students' Writing Skill Viewed from Their Creativity
}

\author{
Fatimah Mulya Sari \\ fatimahmulyasari@gmail.com \\ STBA Teknokrat
}

\begin{abstract}
This article mainly describes the effectiveness of internet-based materials and interaction effect between teaching materials and creativity in tecahing writing for college students. An experimental method was applied in this research. The population was the second semester of English Literature students consisting of 80 students: 40 students as the experimental group and 40 students as the control group. The research instruments used was writing test about an argumentative essay. A pre-test was given in the first meeting to know the validity and the reliability of the instrument. After giving treatments for three meeting, the writer conducted post-test to know the result. The finding of this research leads to the conclusion that the application of internet-based materials is more effective for teaching writing for the second semester of English Literature students. Besides, there is an interaction between tecahing materials and level of creativity. It is recommended that teachers might apply internet-based materials to teach writing for college students and teachers might give information about it to the students in order to enrich insight and get better learning to improve their writing skill. Therefore, it is important to provide high internet access or wi-fi in the class to increase the optimum writing achievement. By providing it, the students may find sample argumentative essays as many as possible to be read and to know the current issues being discussed.
\end{abstract}

Key Words: argumentative essay, creativity, internet-based materials, writing

\section{Introduction}

Writing covers the process of developing ideas, logical thinking, and language forms and transfer them into graphic symbols on a paper by using appropriate conventions including content, organization, vocabulary, language use, and mechanics. Learning to write seems as a developmental process that helps college students to write and choose their own topics. Most of college students may find some difficulties in accomplishing their writing test. It is the most difficult skill for L2 students to master (Richards \& Renandya, 2002). It becomes worst when they have to write an essay such as an argumentative essay. They are still unable to write an effective flow of thoughts to produce their ideas and logical thinking. They still cannot generate and organize the ideas into readable essay. Harmer (2007) states that some of students are not confident enough to write. These difficulties may be influenced by several crucial factors. The insufficient vocabularies and less writing skill to develop and organize the ideas seem to play crucial factors in this case. Their weaknesses in comprehending and mastering grammar also make their writings uneasy to be understood by the reader. The students also often show inconsistency a clear level of formality. As a result, they find it difficult to write a correct sentence in English. As the students are not able to write correct sentences, they get difficulty to express their ideas in paragraphs where they have to make the paragraphs cohesive and coherent. This problem becomes worse because students' creativity influences the learning-teaching process.

In writing, students' creativity as the supporting element plays an important role to produce a good and understandable writing. Creativity is a mental and social process involving the generation of new ideas or concepts, or new associations of the creative mind between existing ideas or concepts. It is an ability to think creatively and to measure one's fluency, flexibility, and originality of a verbal form. In addition, creativity is an ability to form new ideas and combine them to the existing information. High creative students have high motivation and may force themselves to finish any work such as writing. They do their best in writing and commit their time and energy to their essay project by redefining and elaborating ideas, concepts, and problems. On the contrary side, low creative students limit their motivation in a certain condition and dismiss good things before finishing it. They seems to be afraid to take risks to complete their project. Hence, students who have high creativity usually perform better writing than low creative students.

The writing materials can be taken from many sources. One of them is from internet. Teaching writing by internet materials helps students to get input in language learning process. Internet provides us with authentic and 
real communicating English. That is much better than those that are especially designed for course books since it is continuously updated with current issues. Nuttall (1996) mentions main criteria in choosing internet materials for teaching writing such as suitability of content, exploitability, and readability. In the teaching and learning process using internet materials, the teacher provides controlled and determined materials taken from internet. The development with a tight control towards the internet materials becomes the indicator whether the students are able to be more creative in expressing their ideas in the form of argumentative essays. The aim of giving controlled materials is a means to avoid having misconception upon the advantages for both teachers and students. From internet, the needed information and knowledge about argumentative essay including the elements, outlines, important expressions, tips, tricks, and many others can be browsed easily. The more they browse the sites on internet to find related writing materials, the more they read articles to apply, analyze, synthesis, and determine if a certain material is appropriate to what they need. Furthermore, internet provides the students many sites to improve their creativity in writing argumentative essays. Internet seems to be the best means to find any needed stuffs such as pictures, audio, video and articles, which are related to the teaching materials. For example, "LGBT issues" that is popular nowadays. In another point of view, teaching writing by using internet materials needs certain procedures such as deciding the limitation of the sites. Then, internet for tecahing writing also represents an important contribution to the field in terms of advancing the integration of internet technologies in language subjects and promoting communicative approaches that are made operational through the use of collaborative technologies.

Daskalos, et al. (2005) also conducted a research dealing with the use of authentic materials. His research, which entitles "Authentic texts or adapted texts - That is the question! The use of authentic and adapted texts in the study of English in two Swedish upper secondary schools and a study of student and teacher attitudes towards these texts" is aimed at finding out which attitudes teachers and students have towards authentic and adapted texts used in the teaching of English in two Swedish grammar schools. Furthermore, the paper aims at demonstrating the importance of proper text selection in relation to student motivation. To achieve this, a survey was conducted with second year students in two different schools; on top of this, several interviews were conducted with students as well as an interview with a teacher. This was done to demonstrate the different attitudes towards the coursebook and authentic texts and to illustrate the importance of choosing topics that students can relate to. The results show that students preferred to read authentic texts. These texts provided them with interesting topics. The teacher also preferred to use authentic texts and agreed that authentic texts usually created an active classroom, but pointed out that to substitute the coursebook entirely with authentic material was unrealistic. Therefore, a combination of the two types of text would be preferable.

Thus, the researcher is interested to conduct an experimental research entitled "Internet-Based Materials in Enhancing College Students' Writing Skill Viewed from Their Creativity". It will be conducted to know which materials, internet or course books, yield a better improvement in writing performance viewed from students' creativity.

\section{Method}

This study applied quasi-experimental designs as an experimental study. It attempted to give treatments to the experimental group and maintain the control group over all factors that might affect the result of an experiment. The purpose of experimental study is to investigate the cause and effect of teaching materials and students' creativity towards the college students' writing skill. It involved two variables: writing skill of college students as the dependent variable and teaching materials and students' creativity as the independent variable.

The data were collected in form of quantative data. It was used to obtain the needed data. The technique used in this experimental research is by comparing the experimental group having internet materials as the teaching and learning materials and the control group having course books as the main source of teaching and learning materials. They were given different treatments. Before the treatments, the students were classified based on their creativity into high and low. By doing so, it made easy to decide what teaching materials used to students who have high creativity and those who have low creativity. The population of this research was the second semester students of English Literature. There are 80 students, covering 40 students (A) as the experimental group and 40 students (B) as the control group. In analyzing the data, this study applied a descriptive analysis and inferential analysis to know the mean, median, mode, and standard deviation of the writing scores. Normality and homogeneity were used before testing the hypotheses. In addition, Analysis of Variance (ANOVA) was also applied as a statistical device in factorial design. 


\section{Discussion}

In the discussion part, there are some conclusions that can be drawn. This research used data gained from the students' writing scores taken from the contril class treated by using textbook material and experimental class treated by using internet-based material. The data frequency distribution of the students' writing score taught by using internet-based material are as follows:

Table 3.1. Frequency Distribution of Data Experimental Group (A)

\begin{tabular}{|c|c|c|c|c|c|c|}
\hline $\begin{array}{c}\text { Class } \\
\text { Limits }\end{array}$ & $\mathbf{f}_{\mathbf{i}}$ & Tally & $\mathbf{X}_{\mathbf{i}}$ & $\mathbf{X}_{\mathbf{i}^{2}}$ & $\mathbf{f}_{\mathbf{i}} \mathbf{X}_{\mathbf{i}}$ & $\mathbf{f}_{\mathrm{i}} \mathbf{X}_{\mathrm{i}}{ }^{2}$ \\
\hline $68-70$ & 3 & III & 69 & 4761 & 207 & 14283 \\
\hline $71-73$ & 4 & IIII & 72 & 5184 & 288 & 20736 \\
\hline 74-76 & 6 & IIIII I & 75 & 5625 & 450 & 33750 \\
\hline $77-79$ & 9 & IIIII IIII & 78 & 6084 & 702 & 54756 \\
\hline $80-82$ & 8 & IIIII III & 81 & 6561 & 648 & 52488 \\
\hline $83-85$ & 9 & IIIII IIII & 84 & 7056 & 756 & 63504 \\
\hline $86-88$ & 1 & I & 87 & 7569 & 87 & 7569 \\
\hline $\bar{\Sigma}$ & 40 & & & & 3138 & 247086 \\
\hline Mean & 78.45 & & & & & \\
\hline Mode & 78.75 & & & & & \\
\hline Median & 78.83 & & & & & \\
\hline $\mathbf{s}$ & 4.83 & & & & & \\
\hline
\end{tabular}

From the table 3.1 of frequency distribution of data from experimental group (A), it is showed that: the mean of the students' writing is 78.45 ; the mode is 78.75 ; the median is 78.83 ; and the standard deviation is 4.83 . Meanwhile, frequency distribution of data from control group (B) can be seen in the table 3.2, as follows:

Table 3.2. Frequency Distribution of Data Control Group (A)

\begin{tabular}{|c|c|c|c|c|c|c|}
\hline $\begin{array}{c}\text { Class } \\
\text { Limits }\end{array}$ & $\mathbf{f}_{\mathbf{i}}$ & Tally & $\mathbf{X}_{\mathbf{i}}$ & $\mathbf{X}_{\mathbf{i}^{2}}$ & $\mathbf{f}_{\mathbf{i}} \mathbf{X}_{\mathbf{i}}$ & $\mathbf{f}_{\mathbf{i}} \mathbf{X}_{\mathbf{i}}{ }^{2}$ \\
\hline $67-69$ & 1 & I & 68 & 4624 & 68 & 4624 \\
\hline $70-72$ & 5 & IIIII & 71 & 5041 & 355 & 25205 \\
\hline $73-75$ & 10 & IIIII IIIII & 74 & 5476 & 740 & 54760 \\
\hline 76-78 & 9 & IIIII IIII & 77 & 5929 & 693 & 53361 \\
\hline $79-81$ & 11 & IIIII IIIII I & 80 & 6400 & 880 & 70400 \\
\hline $82-84$ & 4 & IIII & 83 & 6889 & 332 & 27556 \\
\hline $85-87$ & 0 & - & & & 0 & 0 \\
\hline$\sum$ & 40 & & & & 3068 & 235906 \\
\hline Mean & 76.70 & & & & & \\
\hline Mode & 79.17 & & & & & \\
\hline Median & 77.59 & & & & & \\
\hline $\mathbf{s}$ & 3.89 & & & & & \\
\hline
\end{tabular}

From the table 3.1 of frequency distribution of data from control group (B), it is showed that: the mean of the students' writing is 76.70; the mode is 79.17 ; the median is 77.59 ; and the standard deviation is 3.89 .

To know whether the population is normal or not, normality test is employed in this research to the writing scores of experimental and control groups in accordance with the creativity level. The result is presented in the table 3.3.

Table 3.3. The Summary of Normality Test

\begin{tabular}{c|c|c|c|c|c|c}
\hline No. & Variables & $\begin{array}{c}\text { Number of } \\
\text { Data }\end{array}$ & $\mathbf{L}_{\mathbf{o}}$ & $\mathbf{L}_{\mathbf{t}}$ & Description & Test Decision \\
\hline 1 & $\mathrm{~A}_{1}$ & 40 & 0.0735 & 0.141 & Normal & $\mathrm{H}_{\mathrm{o}}$ is accepted. \\
\hline 2 & $\mathrm{~A}_{2}$ & 40 & 0.0721 & 0.141 & Normal & $\mathrm{H}_{\mathrm{o}}$ is accepted. \\
\hline 3 & $\mathrm{~B}_{1}$ & 40 & 0.0791 & 0.141 & Normal & $\mathrm{H}_{\mathrm{o}}$ is accepted. \\
\hline 4 & $\mathrm{~B}_{2}$ & 40 & 0.0856 & 0.141 & Normal & $\mathrm{H}_{\mathrm{o}}$ is accepted. \\
\hline
\end{tabular}




\begin{tabular}{c|c|c|c|c|c|c}
\hline 5 & $\mathrm{~A}_{1} \mathrm{~B}_{1}$ & 20 & 0.1087 & 0.190 & Normal & $\mathrm{H}_{\mathrm{o}}$ is accepted. \\
\hline 6 & $\mathrm{~A}_{2} \mathrm{~B}_{1}$ & 20 & 0.1340 & 0.190 & Normal & $\mathrm{H}_{\mathrm{o}}$ is accepted. \\
\hline 7 & $\mathrm{~A}_{1} \mathrm{~B}_{2}$ & 20 & 0.1204 & 0.190 & Normal & $\mathrm{H}_{\mathrm{o}}$ is accepted. \\
\hline 8 & $\mathrm{~A}_{2} \mathrm{~B}_{2}$ & 20 & 0.1157 & 0.190 & Normal & $\mathrm{H}_{\mathrm{o}}$ is accepted. \\
\hline
\end{tabular}

The summary of normality using Lilliefors test reveals that the value $\left(\mathrm{L}_{\mathrm{o}}\right)$ gained are lower than $\mathrm{L}_{\mathrm{t}}$. Thus, it can be stated that all of the samples based on both teaching materials and creativity levels were normal. Meanwhile, the result of the homogeneity test can be seen in the table 3.4, as follows:

Table 3.4. The Summary of Homogeneity Test

\begin{tabular}{c|c|c|c|c|c}
\hline Sample & df & $\mathbf{1} /(\mathbf{d f})$ & $\mathbf{S i}^{\mathbf{2}}$ & $\mathbf{l o g} \mathbf{s i}^{\mathbf{2}}$ & $\mathbf{( d f )} \mathbf{l o g} \mathbf{~ s i}^{\mathbf{2}}$ \\
\hline 1 & 19 & 0.05 & 8.305263 & 0.919353 & 17.47 \\
2 & 19 & 0.05 & 9.923684 & 0.996673 & 18.93679 \\
3 & 19 & 0.05 & 15.73421 & 1.196845 & 22.74005 \\
4 & 19 & 0.05 & 19.83947 & 1.297530 & 24.65307 \\
$\sum$ & & & & & 83.79763 \\
\hline
\end{tabular}

$$
\begin{aligned}
\log \mathrm{s}^{2} & =\log (13.45066)^{2}=1.128744 \\
\mathrm{~B} & =\left(\log \mathrm{s}^{2}\right) \sum\left(\mathrm{n}_{\mathrm{i}}-1\right)=1.128744(76)=85.80872 \\
\chi_{0}^{2} \quad & =(\ln 10)\left\{\mathrm{B}-\sum\left(\mathrm{n}_{\mathrm{i}}-1\right) \log \mathrm{s}_{\mathrm{i}}^{2}\right\} \\
& =(2.3026)(85.78451-83.79763) \\
& =4.57
\end{aligned}
$$

According to the result of homogeneity test, it can be seen that the score of $\chi_{0}^{2}$ is 4.57 . Based on the table of Chi-Square distribution with the significance level $\alpha=0.05$, the value of $\chi_{t}^{2} 0.95(3)$ is 7.81. Because $\chi_{0}^{2}(4.57)$ is lower than $\chi_{t}^{2}$ 0.95(3) $(7.81)$ or $\chi_{0}^{2}<\chi_{t}^{2}(4.57<7.81)$, it can be concluded that the data are homogenous.

From the computation of ANOVA test, it can be concluded that $\mathrm{F}_{\mathrm{o}}$ between columns, the comparative analysis between the effect of tecahing using internet material and coursebook, is 4.952. It is higher than $\mathrm{F}_{t}(3.97)$ which means that there is a significant difference between the means of internet-based material and coursebook material to teach writing. The mean score of the students taught using internet-based material (78.55) is higher than the mean score of the students taught using coursebook (76.70). It is summarized that internet-based material is more effective than coursebook to teach writing.

In addition, there is a significant difference of teaching materials upon writing competence. It can be seen from the value of $F_{o b s}$ which is higher than $F_{\text {table }}$ at the significance level $\alpha=0.05$. The writing materials taken from internet sites are proven to be able to increase college students' ability in writing because the internet-based materials serve many sources of knowledge and information for the college students to achieve more new vocabularies, dictions, styles, and ways to enhance their writing ability in writing argumentative essays.

In a second language learning classroom, creativity plays important role for students of a foreign language because it can affect student's acquisition, invention, and production of the new language. Relating to creativity, it is known as a general ability to produce something new and to share new ideas implemented in problem solving. It can also be said as an ability to understand new relationships among previous elements (Munandar, 1999a). Every student has a different level of creativity which may affect their ways of thinking critically, their behavior, and their competences in all aspects. Thus, creative thinking is an important human characteristic. It is the ebst thought as a process that requires a mixture of ingredients, including personality traits and abilities.

Based on this study, it can be stated that creativity plays an important role in helping students express their ideas in the written form especially in the form of argumentative essays. From the data analysis, it is shown that college students with high creativity are usually the people who are able to come up their ideas to solve the problem. They might be able to show better writing competence in expressing their ideas in an argumentative essay. This results appear since students' creativity help them to choose, select, analyze, and apply the most effective, efficient, and persuasive ways in argumentation. The students with high level of creativity are able to involve both mental and social processes in order to create newly developed critical ideas and convey and share them in written form. One's creativity is about an ability to process a new idea in their mind that is supported by his basic function of intelligence. One's creativity can be seen in his or her eagerness to take part in an activity enthusiastically, to come up with new and fresh idea, to behave assertively, and to share with others. It can be seen from the results of their writing competence when the internet materials were applied in their class. On the other way around, The students 
with low level of creativity will just write what he sees, reads, and listens without being able to think what is beyond. They are unable to come up with their own fresh ideas and opinions when learning. These are some of the reasons why their writing scores are less than those having high creativity. Their low creativity makes them unable to express their ideas better. This can be seen from the results of their writing competence in which the scores of both control and experimental classes are lower than those of having high level of creativity from both classes given treatment.

\section{Conclusion}

It can be concluded that internet-based materials for teaching writing affect a better result of writing performance for college students in the second semester than the materials taken from coursebook or coursebook. It is effective teaching materials of writing subject especially for argumentative essay. Besides, the students having high level of creativity gain higher writing performance especially in argumentative essay than those having low level of creativity in learning writing with materials taken from either internet or coursebooks. Those who have low level of creativity showed similar results of writing performance when learning writing using either internet or coursebook materials. To reach optimum writing achievement, the classroom environment should be provided by an internet access. The teacher also has to provide specific sites dealing with the genre of writing and determining the most current and hottest issues to teach writing. It may help the students to explore the intended materials and find out the sample essays for the selected sites. Thus, it is recommended that the teacher has to apply this internetbased materials for classroom activities in teaching writing and improve the students' writing achievement for the second semester of English Literature students.

\section{References}

Daskalos, K. \& Ling, J.J. (2005). Authentic Text or Adapted Text- That is the Question. Retrieved from: http://dspace.mah.se/bitstream/handle/2043/1964/authenticandadapted.pdf.

Harmer, J. (2007). How to Teach English. Harlow: Pearson Education.

Maurer, M.M. and Davidson, S.G. (2002). Leadership in instructional technology. New Jersey: Prentice Hall Inc.

Munandar. (1999a). Pengembangan Kreativitas Anak Berbakat. Jakarta: Depdiknas dan Rineka Cipta.

Nuttall., C (1996). Teaching Reading Skills in a Foreign Language (2nd Edition). Oxford: Heinemann.

Richards, J. C. and Renandya, W. A. (2002). Methodology in Language Teaching: An Anthology of Current Practice. New York: Cambridge University Press. 